\title{
Gentamicin serum concentrations after reinfusion of blood in patients undergoing arthroplasty with gentamicin-loaded bone cement.
}

\author{
Sergio Daniel Sánchez Rojas ${ }^{1}$, Vicente Casa de Pantoja ${ }^{2}$, Teresa Cabaleiro ${ }^{1}$, Miriam Saiz-Rodríguez ${ }^{1,3}$, María Elena \\ Rodríguez Agüero², Marta Vecino López ${ }^{2}$, Sagrario Lara Baruque ${ }^{4}$, Francisco Abad-Santos ${ }^{1,5,6^{*}}$
}

${ }^{1}$ Clinical Pharmacology Department, Hospital Universitario de La Princesa, Instituto Teófilo Hernando, Universidad Autónoma de Madrid (UAM), Instituto de Investigación Sanitaria La Princesa (IP), Madrid, Spain.

${ }^{2}$ Traumatology Department, Hospital Universitario de La Princesa, Madrid, Spain.

${ }^{3}$ Research Unit, Fundación Burgos por la Investigación de la Salud, Hospital Universitario de Burgos, Burgos, Spain

${ }^{4}$ Clinical Analysis Department, Hospital Universitario de La Princesa, Madrid, Spain.

${ }^{5}$ UICEC Hospital Universitario de La Princesa, Plataforma SCReN (Spanish Clinical Reseach Network), Instituto de Investigación Sanitaria La Princesa (IP),

Madrid, Spain.

${ }^{6}$ Pharmacology Department, Facultad de Medicina, Universidad Autónoma de Madrid, Madrid, Spain.

*Corresponding autor: francisco.abad@salud.madrid.org

\begin{abstract}
:
Cement is sometimes applied to fix prostheses during arthroplasty. The cement can contain antibiotics for prophylaxis or treatment of joint infection. Gentamicin in cement is released gradually into its surroundings and can reach toxic concentrations in recovered blood. To determine gentamicin concentrations in patients with recovered blood and after blood reinfusion in patients who underwent joint replacement using gentamicin-loaded bone cement. This is a prospective observational study of 18 patients who underwent partial or total hip or knee replacement. Gentamicin-loaded bone cement was justified in all cases, and all patients were candidates for blood reinfusion after surgery. Gentamicin serum concentrations were measured by immunoassay. Serum concentrations were never higher than $1.5 \mu \mathrm{g} / \mathrm{ml}$. The median concentration of gentamicin in recovered blood was $26.3 \mu \mathrm{g} / \mathrm{ml}$. The maximum gentamicin dose by blood reinfusion could be $129 \mathrm{mg}$. The maximum gentamicin concentration in reinfused blood was $1.5 \mu \mathrm{g} / \mathrm{ml}$. Gentamicin-loaded bone cement is safe, since drug levels did not reach toxic concentrations.
\end{abstract}

\footnotetext{
Keywords: gentamicin; arthroplasty; bone cements; blood; reinfusion.

Recibido November 10, 2019 Acepted January 10, 2020 Published May 5, 2020.

Copyright: (c) 2020 Authors. This is an open-access article distributed under the terms of the Creative Commons Attribution License, which permits unrestricted use, distribution, and reproduction in any medium, provided the original author and source are credited. Editor: Alberto Borobia

Cite as: Sánchez Rojas S.D., Casa de Pantoja V., Cabaleiro T., Saiz-Rodríguez M., Rodríguez Agüero M.L., Vecino López M., Lara Baruque S., Abad-Santos F.. Gentamicin serum concentrations after reinfusion of blood in patients undergoing arthroplasty with gentamicin-loaded bone cement. IBJ Clin Pharmacol 2020 1(1):e0014. DOI: 10.24217/2530-4984.20v1s1.00014 Funding: There is no funding related to this article.

Competing Interests: F Abad-Santos has been consultant or investigator in clinical trials sponsored by the following pharmaceutical companies: Abbott, Alter, Chemo, Cinfa, FAES, Farmalíder, Ferrer, Galenicum, Gilead, GlaxoSmithKline, Italfarmaco, Janssen-Cilag, Kern, Normon, Novartis, Servier, Silverpharma, Teva, and Zambon. The other authors have no competing interests to disclose.
} 


\section{INTRODUCTION}

Periprosthetic joint infection leads to failure of total joint replacement, with a current prevalence of $1-2 \%$ 1. Cement is sometimes applied to fix prostheses in arthroplasty owing to patient age, comorbidities, or bone quality. Implant-related infections might appear due to the formation of bacterial biofilms 2 . Once the infection begins, it is challenging to treat and severely reduces patient's quality of life 3 .

In order to prevent these type of infections, the cement can contain antibiotics such as gentamicin, vancomycin, or combinations for prophylaxis or treatment of joint infection 4-6. These antibiotics showed excellent eluting and material properties 2,4,7,8. In case of gentamicin, it can be combined with polymethyl methacrylate. Liquid gentamicin is added to cement for its bactericidal properties and it is gradually released to the surrounding area. Initially, high concentrations are reached, although these diminish over time. However, local concentrations can be detected at 3 months 9. Hip and knee arthroplasties cause a significant blood loss which often requires blood transfusions to avoid perioperative anaemia 10,11. To reduce the need of allogenic transfusions, the reinfusion of filtered postoperatively collected drainage blood was settled as a proper technique $12-14$. Then, blood recovery systems are increasingly used during or after surgery 15 . However, as gentamicin can pass to recovered blood, it can reach detectable concentrations in systemic circulation that may cause nephrotoxicity or ototoxicity in this type of patients.

The aim of this study was to determine gentamicin concentrations in recovered blood and serum concentrations after the reinfusion in patients whose prosthesis was fixed using gentamicin-loaded bone cement.

\section{MATERIALS \& METHODS}

Study design

Ours was a pilot, prospective, observational study of 18 patients ( 2 male and 16 female) who underwent total or partial hip or knee replacement and who were candidates for blood reinfusion after surgery.

Arthroplasty using gentamicin-loaded bone cement was justified in all cases. The bone was cemented with Palamed G® 1 x 40 (550 mg of gentamicin for each $40 \mathrm{~g}$ of polymethyl methacrylate). The mean values for cement weight and gentamicin concentrations were very variable. The average weight of the gentamicin-loaded bone cement was $30.98 \mathrm{~g}$ (range, $6-84.6 \mathrm{~g}$ ).

Antibiotic prophylaxis consisted of amoxicillin-clavulanic acid or cefazolin. Patients who were allergic to betalactams received vancomycin. Patients with impaired renal function or gentamicin allergy were excluded.

\section{Quantification of gentamicin}

Three samples were to be drawn: the first, 2 hours after surgery; the second, from recovered blood; and the third, 30 minutes after reinfusion. Gentamicin concentrations were determined using immunoassay (Abbott), following the procedures used in routine care laboratory, as previously described 16 .

Statistical analysis

A descriptive analysis was performed to calculate mean, standard deviation, coefficient of variation, median, geometric mean and minimum and maximum of all continuous variables (age, cement weight and gentamicin concentrations). The correlation between gentamicin levels and cement weight was investigated by linear regression. $\mathrm{P}$ values lower than 0.05 were considered significant. The statistical analysis was performed using SPSS software v.15.0.

\section{Ethics}

The protocol complied with Spanish law on biomedical research and was approved by the Ethics Committee for Clinical Investigation of Hospital Universitario de la Princesa. Written informed consent was obtained from each patient before inclusion in the study

\section{RESULTS}

Seven patients underwent partial hip replacement surgery, 1 total hip replacement and 10 total knee re-placement. Mean age was $80.72 \pm 8.68$ years old. None of the patients developed nephrotoxicity or infection.

Table 1 shows gentamicin concentrations measured in serum 2 hours after surgery, in recovered blood, and in serum 30 minutes after reinfusion. However, the 3 settled samples could not be collected from the 18 patients.

The highest serum concentration 2 hours after surgery was $1.3 \mu \mathrm{g} / \mathrm{ml}$ (mean of $0.56 \pm 0.43 \mu \mathrm{g} / \mathrm{ml}$ ). Gentamicin concentrations in recovered blood ranged from 1.2 to $129 \mu \mathrm{g} / \mathrm{ml}$ (mean of $34.44 \pm 32.83 \mu \mathrm{g} / \mathrm{ml}$ ). Therefore, the maximum gentamicin dose would be $129 \mathrm{mg}$ if the maximum volume (1 L) was reinfused.

Recovered blood was finally reinfused in 5 patients. The blood volume never exceeded $1 \mathrm{~L}$. The maximum serum gentamicin concentration after reinfusion was $1.5 \mu \mathrm{g} / \mathrm{ml}$ (mean of $0.76 \pm 0.50 \mu \mathrm{g} / \mathrm{ml}$ ), that is, much lower than the recommended trough level $(<2 \mu \mathrm{g} / \mathrm{ml}) 17$.

A correlation was observed between cement weight and gentamicin concentration (Figure 1). We observed that the greater the weight of the cement, the higher the concen-tration of gentamicin found in serum 2 hours after surgery, in recovered blood, and in serum 0.5 hours after reinfusion (Figure 1). We also found a correlation between gentamicin concentration in drained blood and in serum after reinfu-sion (Figure 2). 
Table 1

\begin{tabular}{|c|c|c|c|c|c|c|c|}
\hline \multirow[b]{2}{*}{ Patient } & \multirow[b]{2}{*}{ Sex } & \multirow[b]{2}{*}{ Age } & \multirow[b]{2}{*}{ Joint } & \multirow[b]{2}{*}{$\begin{array}{l}\text { Cement } \\
\text { Weight }\end{array}$} & \multicolumn{3}{|c|}{ Gentamicin conc entrations $(\mu \mathrm{g} / \mathrm{ml})$} \\
\hline & & & & & $\begin{array}{l}\text { Serum } \\
\text { (2 h after } \\
\text { surgery) }\end{array}$ & $\begin{array}{l}\text { Recorered } \\
\text { blood }\end{array}$ & $\begin{array}{c}\text { Serum } \\
\text { ( } 0.5 \mathrm{~h} \text { after infusion of } \\
\text { recovered blood) }\end{array}$ \\
\hline 1 & $\bar{F}$ & 85 & PHR & 14.0 & 0 & 26.3 & \\
\hline 2 & $\mathrm{~F}$ & 72 & TKR & 7.2 & 0.5 & 12.6 & 0.5 \\
\hline 3 & $\mathrm{M}$ & 76 & TKR & 6.0 & 0.5 & & \\
\hline 4 & F & 76 & TKR & 10.5 & & 28.4 & \\
\hline 5 & F & 89 & PHR & 25.0 & 0.4 & 4.1 & \\
\hline 6 & F & 83 & THR & 28.0 & 0.4 & 38.7 & \\
\hline 7 & F & 80 & PHR & 13.0 & & 1.2 & \\
\hline 8 & F & 84 & PHR & 20.0 & & 34.8 & 0.6 \\
\hline 9 & F & 79 & TKR & 16.5 & & 22.5 & 0.2 \\
\hline 10 & F & 80 & TKR & 57.5 & 1.3 & 14.6 & \\
\hline 11 & $\mathrm{~F}$ & 55 & TKR & 18.3 & 0.3 & & \\
\hline 12 & F & 77 & TKR & 84.6 & & 66.4 & \\
\hline 13 & $F$ & 83 & PHR & 12.9 & & 6.40 & \\
\hline 14 & $\mathrm{~F}$ & 86 & TKR & 81.0 & & 129 & \\
\hline 15 & $\mathrm{~F}$ & 95 & PHR & 21.0 & 1.1 & & \\
\hline 16 & $\mathrm{~F}$ & 92 & PHR & 19.2 & & 23.5 & 1 \\
\hline 26 & $F$ & 78 & TKR & 60.0 & & 66.2 & \\
\hline 27 & $\mathrm{M}$ & 83 & TKR & 63.0 & & 41.9 & 1.5 \\
\hline $\mathbf{N}$ & & 18 & & 18 & 8 & 15 & 5 \\
\hline Mean & & 80.72 & & 30.98 & 0.56 & 34.44 & 0.76 \\
\hline $\mathrm{SD}$ & & 8.68 & & 25.75 & 0.43 & 32.83 & 0.50 \\
\hline $\mathrm{CoV} \%$ & & 0.11 & & 0.83 & 0.76 & 0.95 & 0.66 \\
\hline Median & & 81.50 & & 19.60 & 0.45 & 26.30 & 0.60 \\
\hline GM & & 80.23 & & 22.77 & 0 & 21.10 & 0.62 \\
\hline Min. & & 55.00 & & 6.00 & 0.00 & 1.20 & 0.20 \\
\hline Max. & & 95.00 & & 84.60 & 1.30 & 129.00 & 1.50 \\
\hline
\end{tabular}

PHR: Partial hip replacement. THR: Total hip replacement. TKR: Totalknee replacement. F:

Female. M: Male. GM: Geometric mean. Min:

Minimum. Max: Maximum

(A)

(B)
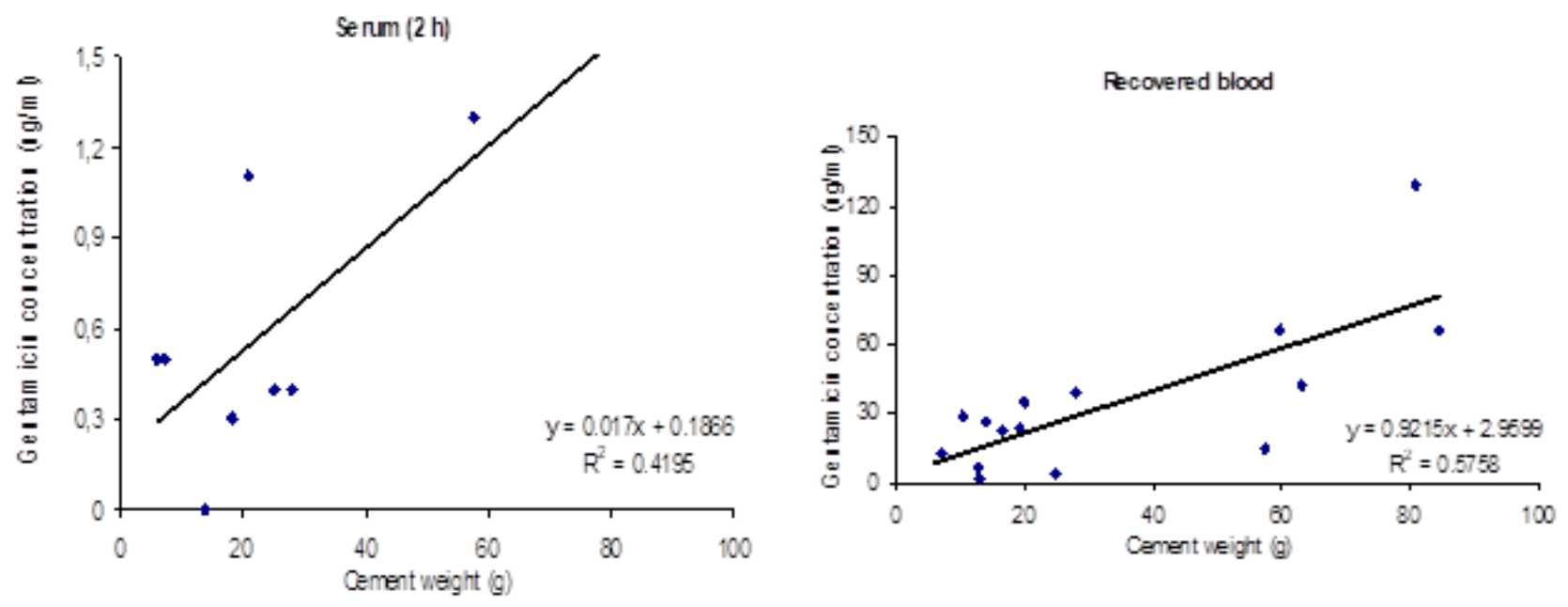
(C)

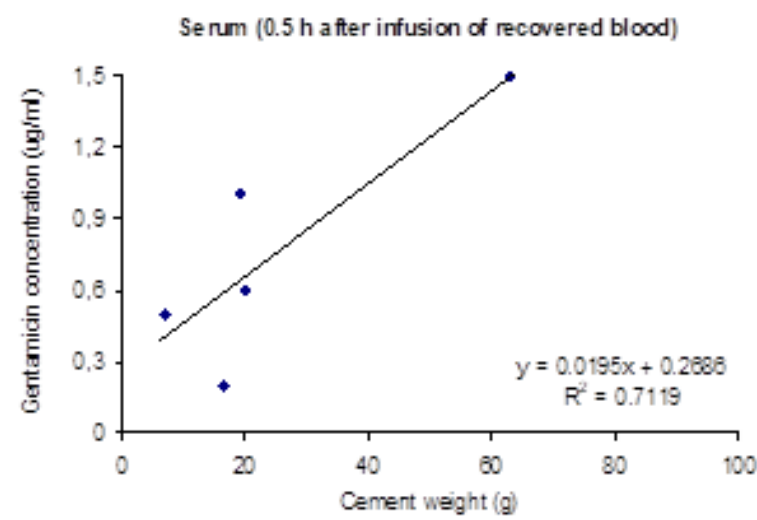

Figure 1. Correlation between cement weight in each patient and serum gentamicin concentrations 2 hours after surgery (A), gentamicin concentrations in recovered blood (B), and serum gentamicin concentrations 0.5 hours after infusion of recovered blood (C).

\section{DISCUSSION}

Arthroplasty has become a routine procedure in recent years, although postsurgical bacterial infection remains a significant complication 18 . One approach to reducing the incidence of joint infection after arthroplasty involves antibiotic-impregnated bone cement to fix the implant 19 . Local antibiotics provide high tissue concentrations and minimize systemic toxicity, especially nephrotoxicity. Thus, the use of antibiotic-impregnated cement lowered the infection rate by approximately $50 \%$ in primary hip arthroplasty, with no reported adverse events or complications 20 . Fink et al. 21 showed that antibiotic concentrations 6 weeks after spacer implantation were sufficient to treat a periprosthetic infection.

However, little is known about the release of antibiotic from bone cement during the days immediately following surgery in humans. Release of vancomycin in vitro is related to the surface area of the vancomycin-loaded spacers 22: increasing the surface-to-volume ratio could enhance release.

In our study (550 mg of gentamicin in $40 \mathrm{~g}$ of cement), we found the mean gentamicin concentration in recovered blood to be $34.44 \mu \mathrm{g} / \mathrm{ml}$. Bálint et al. 23 reported release of gentamicin from bone cement ( $1.48 \mathrm{~g}$ gentamicin in $40 \mathrm{~g}$ cement) in the period immediately following total hip arthroplasty. The amount of gentamicin in the wound fluid was inversely proportional to the total amount excreted. Mean gentamicin concentrations in the drain fluid di-minished $(2.6,1.2$, and $0.6 \mu \mathrm{g} / \mathrm{ml}$, respectively at 6,24 , and 48 hours after surgery) but remained above the minimal inhibitory concentration.

We found that gentamicin concentrations were low in serum $(0.56 \pm 0.43 \mu \mathrm{g} / \mathrm{ml})$ but high in drained blood $(34.44 \pm 32.83 \mu \mathrm{g} / \mathrm{ml})$. A similar finding was observed in a randomised, double-blind study performed in 2 groups of 15 patients undergoing total hip replacement

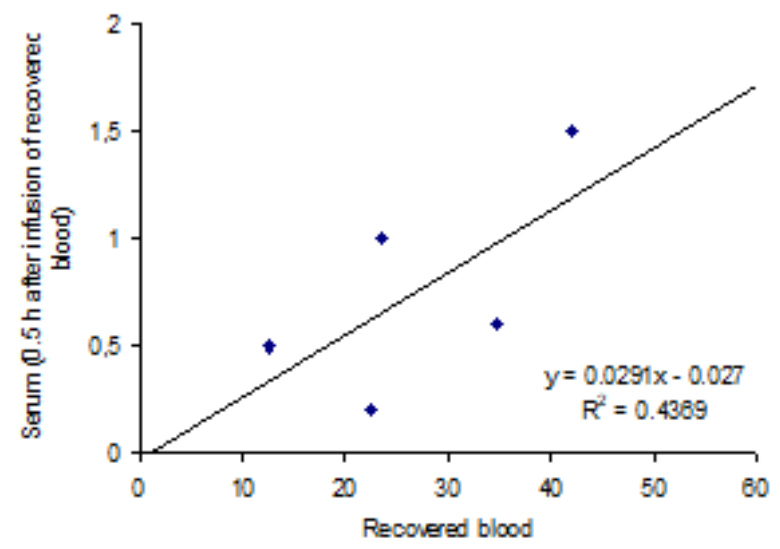

Figure 2. Correlation between gentamicin concentration in recovered blood and serum concentration 0.5 hours after infusion of recovered blood.

using antibiotic-loaded acrylic cement $(0.5 \mathrm{~g}$ and $1.0 \mathrm{~g}$ gen-tamicin per $40 \mathrm{~g}$ of polymer, respectively) 24 : for both gentamicin doses, the serum concentrations were low, whereas the wound drainage fluid contained highly ef-fective antibacterial concentrations. The authors found that the highest concentration of gentamicin in serum was at 0.5 hours in both groups $(1.45 \mu \mathrm{g} / \mathrm{ml}$ and $2.9 \mu \mathrm{g} / \mathrm{ml}$, for $0.5 \mathrm{~g}$ and $1 \mathrm{~g}$ doses, respectively). In drained blood, the concentration reached $100 \mu \mathrm{g} / \mathrm{ml}$ for the $0.5-\mathrm{g}$ dose and $308 \mu \mathrm{g} / \mathrm{ml}$ for the $1-\mathrm{g}$ dose. The authors also found that serum, urine, and wound secretion levels showed approximately 2-fold higher concentrations in the group of patients receiving the higher gentamicin load.

Hsieh et al. 9 investigated the application of gen-tamicinloaded bone cement to treat musculoskeletal infections. Forty-two patients undergoing 2-stage revision hip arthroplasty for periprosthetic infection were managed with an interim cement spacer loaded with liquid gentamicin (480 mg per $20 \mathrm{ml}$ cement). Systemic antibiotic concentrations were below detectable levels in most patients, and no nephrotoxicity was detected.

The delivery of gentamicin (1.9\%) and vancomycin $(2.5 \%)$ from polymethyl methacrylate spacers before and after implantation for the treatment of total hip replacement infections was evaluated by Bertazzoni Minelli et al. 25 . The release kinetics showed a similar pattern for both antibiotics: release was high initially, but gradually levelled off over the following months.

Anagnostakos et al. 26 also studied the release of gentamicin and vancomycin $(1 \mathrm{~g}$ and $4 \mathrm{~g}$ per $80 \mathrm{~g}$ of cement, respectively) in drainage fluid from 28 patients. Systemic antibiotics were given postoperatively according to the antibiogram, and gentamicin and vancomycin were avoided when possible. Mean peak concentrations were reached for gentamicin and vancomycin on day 1 , with no renal or hepatic dysfunction. The authors stressed the importance of additional systemic antibiotics for this procedure during the postoperative period owing to the 
inferior release properties of spacers.

Regis et al. 27 studied gentamicin and vancomycin concentrations in drainage fluid obtained from patients with infected total hip arthroplasty during the first 24 hours after implantation of antibiotic-loaded polymethyl methacrylate spacers. Gentamicin and vancomycin were released from temporary hip spacers at bactericidal concentrations, whereas serum levels were below the limit of detection.

None of the patients in our study developed adverse events, although other research groups described several. Though nephrotoxicity is uncommon, there have been some reports of acute renal failure after surgery involving antibiotic-impregnated cement in infected total knee and hip arthroplasty 28-31.

Finally, our study is limited by the small sample size, since only 5 patients were reinfused. However, considering this as an exploratory study, our data show the correlation between cement weight and gentamicin concentrations, which is important to take into account for further ap-proaches. However, even in heavier cement prosthesis, gentamicin did not reach toxic levels. Thus, our data indicate that gentamicin-loaded bone cement is safe in patients undergoing arthroplasty, even in those receiving reinfused blood.

\section{ACKNOWLEGEMENTS}

We are grateful to Mr. Thomas O’Boyle for editorial assistance. This study would not have been possible without the cooperation of the patients.

\section{REFERENCES}

[1]. Osmon DR, Berbari EF, Berendt AR, Lew D, Zimmer-li W, Steckelberg JM, et al. Diagnosis and manage-ment of prosthetic joint infection: clinical practice guidelines by the Infectious Diseases Society of America. Clin Infect Dis Off Publ Infect Dis Soc Am. 2013 Jan;56(1):e1-25.

[2]. Neut D, Dijkstra RJ, Thompson JI, Kavanagh C, van der Mei HC, Busscher HJ. A biodegradable gentamicin-hydroxyapatite-coating for infection prophylaxis in cementless hip prostheses. Eur Cell Mater. 2015 Jan 2;29:42-55; discussion 55-56.

[3]. Manoj Kumar R, Haldar S, Rajesh K, Ghosh S, Lahiri D. Comparative study on the efficacy of the UHMWPE surface modification by chemical etching and electrostatic spraying method for drug release by orthopedic implants. Mater Sci Eng C. 2019 Dec;105:110117.

[4]. Wouthuyzen-Bakker M, Löwik CAM, Knobben BAS, Zijlstra WP, Ploegmakers JJW, Mithoe G, et al. Use of gentamicin-impregnated beads or sponges in the treatment of early acute periprosthetic joint infection: a propensity score analysis. J Antimicrob Chemother. 2018 01;73(12):3454-9.

[5]. Kunutsor SK, Beswick AD, Whitehouse MR, Wylde V, Blom AW. Debridement, antibiotics and implant retention for periprosthetic joint infections: A sys- tematic review and meta-analysis of treatment outcomes. J Infect. 2018;77(6):479-88.

[6]. Oh EJ, Oh SH, Lee IS, Kwon OS, Lee JH. Antibiotic-eluting hydrophilized PMMA bone cement with prolonged bactericidal effect for the treatment of osteomyelitis. J Biomater Appl. 2016 May;30(10):153444.

[7]. Gálvez-López R, Peña-Monje A, Antelo-Lorenzo R, Guardia-Olmedo J, Moliz J, Hernández-Quero J, et al. Elution kinetics, antimicrobial activity, and mechanical properties of 11 different antibiotic loaded acrylic bone cement. Diagn Microbiol Infect Dis. 2014 Jan;78(1):70-4.

[8]. Chang Y, Tai C-L, Hsieh P-H, Ueng SWN. Gentamicin in bone cement: A potentially more effective prophylactic measure of infectionin joint arthro-plasty. Bone Jt Res. 2013;2(10):220-6.

[9]. Hsieh P-H, Huang K-C, Tai C-L. Liquid gentamicin in bone cement spacers: in vivo antibiotic release and systemic safety in two-stage revision of infected hip arthroplasty. J Trauma. 2009 Mar;66(3):804-8.

[10]. Bierbaum BE, Callaghan JJ, Galante JO, Rubash HE, Tooms RE, Welch RB. An analysis of blood manage-ment in patients having a total hip or knee arthro-plasty. J Bone Joint Surg Am. 1999 Jan;81(1):210 .

[11]. Rosencher N, Kerkkamp HEM, Macheras G, Munuera LM, Menichella G, Barton DM, et al. Orthopedic Surgery Transfusion Hemoglobin European Over-view (OSTHEO) study: blood management in elec-tive knee and hip arthroplasty in Europe. Transfu-sion (Paris). 2003 Apr;43(4):459-69.

[12]. Strümper D, Weber EWG, Gielen-Wijffels S, Van Drumpt R, Bulstra S, Slappendel R, et al. Clinical ef-ficacy of postoperative autologous transfusion of filtered shed blood in hip and knee arthroplasty. Transfusion (Paris). 2004 Nov;44(11):1567-71.

[13]. Jones HW, Savage L, White C, Goddard R, Lumley $\mathrm{H}$, Kashif F, et al. Postoperative autologous blood salvage drains--are they useful in primary uncemented hip and knee arthroplasty? A prospective study of 186 cases. Acta Orthop Belg. 2004 Oct;70(5):466-73.

[14]. Mirza SB, Campion J, Dixon JH, Panesar SS.

Efficacy and economics of postoperative blood salvage in pa-tients undergoing elective total hip replacement. Ann R Coll Surg Engl. 2007 Nov;89(8):777-84.

[15]. Rees JE, Jeavons R, Dixon JH. An economic justification for autologous blood re-infusion in primary total knee replacement surgery. Ann R Coll Surg Engl. 2005 Mar;87(2):102-5.

[16]. Wei TQ, Chu VP, Craig AR, Duffy JE, Obzansky DM, Kilgore D, et al. Automated homogeneous immuno-assay for gentamicin on the dimension clinical chemistry system. Clin Chem. 1999 Mar;45(3):388-93.

[17]. Agencia Española de Medicamentos y Productos Sanitarios (AEMPS) label information for gentamicine. Available at: https:/cima.aemps.es/cima/ dochtml/ft/63854/FichaTecnica_63854.html Accessed 
December 04, 2019.

[18]. Haaker R, Senge A, Krämer J, Rubenthaler F. [Osteo-myelitis after endoprostheses]. Orthopade. 2004 Apr;33(4):431-8.

[19]. Dunbar MJ. Antibiotic bone cements: their use in routine primary total joint arthroplasty is justified. Orthopedics. 2009 Sep;32(9).

[20]. Parvizi J, Saleh KJ, Ragland PS, Pour AE, Mont MA. Efficacy of antibiotic-impregnated cement in total hip replacement. Acta Orthop. 2008 Jun;79(3):335-41.

[21]. Fink B, Vogt S, Reinsch M, Büchner H. Sufficient release of antibiotic by a spacer 6 weeks after implantation in two-stage revision of infected hip prostheses. Clin Orthop. 2011 Nov;469(11):3141-7.

[22]. Holtom PD, Warren CA, Greene NW, Bravos PD, Ressler RL, Shepherd L, et al. Relation of surface area to in vitro elution characteristics of vancomy-cinimpregnated polymethylmethacrylate spacers. Am J Orthop Belle Mead NJ. 1998 Mar;27(3):207-10.

[23]. Bálint L, Koós Z, Horváth G, Szabó G. Detection of gentamicin emission from bone cement in the early postoperative period following total hip arthroplasty. Orthopedics. 2006;29(5):432-6.

[24]. Wahlig H, Dingeldein E, Buchholz HW, Buchholz M, Bachmann F. Pharmacokinetic study of gentamicin-loaded cement in total hip replacements. Comparative effects of varying dosage. J Bone Joint Surg Br. 1984 Mar;66(2):175-9.

[25]. Bertazzoni Minelli E, Benini A, Magnan B, Bartoloz-zi P. Release of gentamicin and vancomycin from temporary human hip spacers in two-stage revision of infected arthroplasty. J Antimicrob Chemother. 2004 Feb;53(2):329-34.

[26]. Anagnostakos K, Wilmes P, Schmitt E, Kelm

J. Elu-tion of gentamicin and vancomycin from polymethylmethacrylate beads and hip spacers in vivo. Acta Orthop. 2009 Apr;80(2):193-7.

[27]. Regis D, Sandri A, Samaila E, Benini A, Bondi M,
Magnan B. Release of gentamicin and vancomycin from preformed spacers in infected total hip arthroplasties: measurement of concentrations and inhibitory activity in patients' drainage fluids and serum. ScientificWorldJournal. 2013;2013:752184.

[28]. Curtis JM, Sternhagen V, Batts D. Acute renal failure after placement of tobramycin-impregnated bone ce-ment in an infected total knee arthroplasty. Pharmacotherapy. 2005 Jun;25(6):876-80.

[29]. van Raaij TM, Visser LE, Vulto AG, Verhaar JAN. Acute renal failure after local gentamicin treatment in an infected total knee arthroplasty. J Arthroplasty. 2002 Oct;17(7):948-50.

[30]. Patrick BN, Rivey MP, Allington DR. Acute renal failure associated with vancomycin- and tobramycin-laden cement in total hip arthroplasty. Ann Pharmacother. 2006 Nov;40(11):2037-42.

[31]. Dovas S, Liakopoulos V, Papatheodorou L, Chronopoulou I, Papavasiliou V, Atmatzidis E, et al. Acute renal failure after antibiotic-impregnated bone cement treatment of an infected total knee arthroplasty. Clin Nephrol. 2008 Mar;69(3):207-12. 